\title{
Money Supply and Inflation in Nigeria: Implications for National Development
}

\author{
Olorunfemi Sola, Adeleke Peter \\ Department of Economics, Adekunle Ajasin University, Akungba, Nigeria \\ Email: olorunfemi@adekunleajasinuniversity.edu.ng
}

Received September 6, 2012; revised October 25, 2012; accepted November 28, 2012

\begin{abstract}
The study examines money supply and inflation rate in Nigeria. Secondary data that ranged between 1970-2008 were sourced from the CBN Statistical Bulletin. The study used Vector Auto Regressive (VAR) model. The stationary properties of the model were also explored. The results revealed that money supply and exchange rate were stationary at the level while oil revenue and interest rate were stationary at the first difference. Results from the causality test indicate that there exists a unidirectional causality between money supply and inflation rate as well as interest rate and inflation rate. The causality test runs from money supply to inflation, from the interest rate to inflation and from interest rate to money supply. The paper concludes that government should use the level of inflation as an operational guide in measuring the effectiveness of its monetary policy.
\end{abstract}

Keywords: Money Supply; Inflation; Development and VAR

\section{Introduction}

One of the macroeconomic challenges facing Nigeria governments in economic history has been the maintenance of price stability. The subject matter of inflation has received diverse attention due to its sensitivity to economic issues.

There has been an upsurge in inflationary rates leading to major economic distortions in Nigeria since the late 1970s, consequent to civil war, salary increment, and excess government spending. The gradual, but increasing, inflation rate became serious during the 1980s which was marked by several military interventions in governance. Within this period, the various military leaders who came into power pursued expansionary policies in economic management. The adoption of the Structural Adjustment Programme (SAP), in 1986, was for the purpose of restructuring and diversifying the productive base of the economy so as to reduce dependency on the oil sector and imports. Inflationary pressures during the SAP era of 1986-1990 was due largely to sundry factors, especially whole sale depreciation of the Naira on the foreign exchange market, which increased the Naira prices of imported goods including raw materials and capital goods as well as an unprecedented growth in money supply during the period (Onoh, 1990) [1]. The outcome was a huge balance of payment deficit.

Although the magnitude of the inflationary rate continues to vary overtime, all sectors of the economy have been affected by the shocks. The signs closely associated with these shocks are huge balance of payment deficits, high rates of inflation, declining domestic savings, growing government expenditure, falling agricultural production, decreased utilization of industrial capacity, poor transportation infrastructure, and poor levels of social services. All these problems were financed through proceeds of the oil boom which resulted in increases in money supply and the subsequent effects on the economy through high general price levels.

Inflation, in the mid 1990's, became worse due to sanctions against Nigeria by the international community. In the era of democracy which started in May, 1999, Nigeria could not get to the single digit target level of inflation that it had achieved in the 1950s and the early 1960s. Though various fiscal and monetary policies were adopted by government to reduce the high and variable rates of inflation to a single and a relatively stable digit, there has not been any remarkable success due to some constraints such as instability of government, instability of Naira's exchange rate, increased fiscal deficits, inadequate policy co-ordination and unsustainable pressure on balance of payments. The problem of inflation in Nigeria is chiefly associated with the failure to address the structural weakness in the economy, especially the failure to diversify the economy, and reduce dependence on oil exports. Given the major distortions caused by inflation on the country's economic growth and the living standard of the citizenry, it is pertinent therefore to look 
at money supply and inflation in Nigeria. Questions that arise then include the following:

1) Is there any relationship between money supply and inflation?

2) What are the determinants of inflation in Nigeria?

These are some of the questions this study attempts to answer. To be able to answer these questions, the study sets out to analyse the effect(s) of increase in money supply on inflation in Nigeria. The study's specific objectives however, are:

1) To identify the key determinants of inflation in $\mathrm{Ni}$ geria.

2) To determine the relationship between inflation and money supply.

3) To examine the trends and magnitudes of inflation in Nigeria.

The rest of the paper is organized as follows: Section 2 presents review of literature, Section 3 contains methodology, Section 4 presents result and Section 5 provides policy implication and conclusion.

\section{Review of Literature}

Inflation has been widely described as an economic situation where increase in money supply is faster than the new production of new goods and services in the same economy (Hamilton, 2001) [2]. According to Vaish (1999) [3], inflation is a sustained rise in the general price level brought about by high rate of expansion in the aggregate money supply. Inflation emerges in the economy on account of the increase in the money income of certain sectors of the economy without any corresponding increase in their productivity, giving rise to an increase in the aggregate demand for goods and services which cannot be met at the current prices by the total available supply of goods and services in the economy.

The relationship between money supply and inflation is a very common debate in the economic literature. Many economists have analyzed the relationship among these variables over many years. At international level, such studies include Chhibber et al. (1998) [4] that employed a highly disaggregated econometric model for Zimbabwe. They found that monetary growth, foreign prices, exchange and interest rates, unit labour cost, and real output are the key determinants of inflation in that country. In a study for the African Economic Research Consortium (AERC), Kilindo (1997) [5] tried to increase our understanding of Tanzanian's inflation by investigating the links among fiscal operations, money supply and inflation. Finding a strong relationship among the three, he recommended the adoption of a restrictive monetary policy in which the supply of money must be constrained to grow steadily at the rate of growth of real output.
In another study for AERC, Barungi (1997) [6] examined the determinants of inflation in Uganda. The study analysed the relative importance of monetary, cost-push and supply related causes of inflation. He concluded that inflation in Uganda was persistently a monetary phenomenon. Also, Laryea and Sumaila (2001) [7] looked into the determinants of inflation in Tanzania and the study established that in the short-run, output and monetary factors are the main determinants of inflation in Tanzania. They also pointed out that in the long-run, parallel exchange rate also influences inflation. In their conclusion, they emphasized that; inflationary situation in Tanzania is basically a monetary phenomenon.

There are many studies in Nigeria that looked at the relationship between inflation and money supply, such as Oyejide (1972) [8], Itua (2000) [9] and Iyoha (2002) [10]. While some economists found negative relationships, most of economists found positive relationships. Ajisafe (1996) [11] used an error-correction model (ECM) to examine the cause of inflation in Nigeria. He reported that money supply, real gross domestic product, previous level of inflation and exchange rate cause inflation in Nigeria. Ajisafe's study was preoccupied with the monetary factors that could cause inflation, at the expense of fiscal factors. But fiscal factors cannot be ignored in a country like Nigeria where deficit spending has become a more or less permanent feature of the budgetary process (Folorunso and Abiola, 2000 [12]). Osakwe (1983) [13] attempted to verify the amount of government expenditure that affected money supply in the ten-year period 1970-1980 by using quarterly data. Significant statistical evidence obtained from the analysis showed strong relationships between increases in net current expenditure and growth in money supply, and growth in money supply and inflation, on the other. Further increases in money wage rate and money supply (with a lag in effect) were identified as the two most important factors that influenced the movement of prices during the period. An important Conference on the Nigerian inflation process was organized by the Nigerian Institute of Social and Economic Research (NISER) in Ibadan in 1974. In general, the findings of some of the key papers - such as Onitiri and Awosika (1982) [14] suggested that neither monetary nor structural phenomenon alone explained Nigeria's inflation. One striking conclusion from this conference was that a combination of both factors precipitates the inflation process. The quantitative impact of monetary expansion and exchange rate depreciation on price inflation in Nigeria was the focus of Egwaikhide et al. (1994) [15], who used time series econometric techniques of co integration and Error Correction Mechanism (ECM). They concluded that Nigeria's inflation seems to find explanation in both monetary and structural factors and that both the official and the parallel market ex- 
change rates exert upward pressure on the general price level. They recommended the use of a combination of policy measures to put inflation under effective control in Nigeria.

Since each of these studies gives conflicting results, the present study intends to identify the determinant(s) of inflation in Nigeria, as well as examine the impact of money supply on inflation in Nigeria.

\section{Methodology}

\subsection{Model Specification}

With respect to the structure of the Nigerian economy as well as the inflationary trend in Nigeria, the inflation function adopted in this study is largely related to the dynamic factors of economic development. The key determinants of inflation in Nigeria are traceable to such variables as government expenditure, money supply, and interest rate. The modified version of the model earlier formulated by Abdul Majid (2007) [16] is adapted in this study.
That is, this study work adopts a VAR model of Abdul Majid (2007) [16] as follows:

$$
\alpha_{t}=\sum_{i=1}^{k} A_{i} \alpha_{t-i}+\varepsilon_{t}
$$

where;

$\alpha_{t}=$ is column vector of observations at time " $t$ " on all the variables in the model; i.e, $\alpha=\left(\operatorname{Infr}_{t}, \mathrm{Msply}_{t}, \mathrm{Exhr}_{t}\right.$, Intr $\left._{t}, \operatorname{Gexp}_{t}, \mathrm{Oilrev}_{t}\right)$. "Infr" represents Inflation Rate, "Msply" represents Money Supply, "Exhr" represents Real Exchange rate, "Intr" represents Real Interest Rate, "Gexp" represents Total Government Expenditure, "Oil rev" represents Oil Revenue and " $t$ " is time period.

$\Sigma=$ summation of exogenous variables at time " $t$ ".

$\alpha_{t-i}=$ lag of endogenous variables.

$\varepsilon_{t}=v_{1}-v_{6}$ are the impulses or innovations or shocks.

$A_{i}=\chi_{1}-\chi_{6}, \Omega_{1}-\Omega_{6}, \Psi_{1}-\Psi_{6}, \Pi_{1}-\Pi_{6}, \varphi_{1}-\varphi_{6}, \lambda_{1}-\lambda_{6}$ are numbers of parameters to be estimated in Equations (2) to (7).

In a VAR linear form, Equation (1) is given as follows:

$$
\begin{aligned}
& \operatorname{Inf}_{t}=\chi_{1} \operatorname{Msply}_{t-1}+\chi_{2} \operatorname{Inf}_{t-1}+\chi_{3} \operatorname{Exhr}_{t-1}+\chi_{4} \operatorname{Intr}_{t-1}+\chi_{5} \operatorname{Gexp}_{t-1}+\chi_{6} \operatorname{Oilrev}_{t-1}+v_{1} \\
& \text { Msply }_{t}=\Omega_{1} \text { Msply }_{t-1}+\Omega_{2} \operatorname{Inf}_{t-1}+\Omega_{3} \text { Exhr }_{t-1}+\Omega_{4} \operatorname{Intr}_{t-1}+\Omega_{5} \text { Gexp }_{t-1}+\Omega_{6} \text { Oilrev }_{t-1}+v_{2} \\
& \operatorname{Exhr}_{t}=\Psi_{1} \text { Msply }_{t-1}+\Psi_{2} \operatorname{Inf}_{t-1}+\Psi_{3} \operatorname{Exhr}_{t-1}+\Psi_{4} \operatorname{Intr}_{t-1}+\Psi_{5} \operatorname{Gexp}_{t-1}+\Psi_{6} \text { Oilrev }_{t-1}+v_{3} \\
& \text { Intr }_{t}=\Pi_{1} \text { Msply }_{t-1}+\Pi_{2} \operatorname{Inf}_{t-1}+\Pi_{3} \text { Exhr }_{t-1}+\Pi_{4} \operatorname{Intr}_{t-1}+\Pi_{5} \operatorname{Gexp}_{t-1}+\Pi_{6} \text { Oilrev }_{t-1}+v_{4} \\
& \operatorname{Gexp}_{t}=\varphi_{1} \mathrm{Msply}_{t-1}+\varphi_{2} \operatorname{Inf}_{t-1}+\varphi_{3} \operatorname{Exhr}_{t-1}+\varphi_{4} \operatorname{Intr}_{t-1}+\varphi_{5} \operatorname{Gexp}_{t-1}+\varphi_{6} \text { Oilrev }_{t-1}+v_{5} \\
& \text { Oilrev }_{t}=\lambda_{1} \text { Msply }_{t-1}+\lambda_{2} \operatorname{Inf}_{t-1}+\lambda_{3} \operatorname{Exhr}_{t-1}+\lambda_{4} \operatorname{Intr}_{t-1}+\lambda_{5} \operatorname{Gexp}_{t-1}+\lambda_{6} \text { Oilrev }_{t-1}+v_{6}
\end{aligned}
$$

Equations (2) to (7) show the structure of the Vector Autoregression (VAR) model used in the study to capture the linear interdependencies among the variables used. All the variables are treated symmetrically; each variable has an equation explaining its evolution based on its own lags and the lags of all the other variables in the models.

\subsection{Analytical Techniques}

In econometrics, there is the possibility of delay on the part of endogenous variables $(y)$ to respond to changes in exogenous variables $\left(x_{1}, x_{2}, x_{3}, \cdots, x_{n}\right)$. To take care of such delay in response to changes (lag), it is necessary to use models that involve lags in exogenous variables, or endogenous variables, or both.

Vector Auto-Regression (VAR) is an econometric model of stationary time series in which the equation has the same right-hand side variables consisting of exogenous variables and the lagged values of all endogenous variables in the system. VAR is used to investigate the external shocks or effects on the endogenous variables using the impulse response function. All variables in a VAR are treated symmetrically by including each variable and its own lags and the lags of all the other variables in the model. The impulse response function of any VAR model traces the effect of one standard deviation shock to one of the innovations on current and future values of the endogenous variables. The variance decomposition on the other hand shows the fraction of the forecast error variable for each variable that is attributable to its own innovations and the innovation in the other variables in the system. To ascertain the degree of stationarity of variables employed in this study, the unit root problem was tested by using Augmented Dickey Fuller (ADF) test. A granger-causality test is further carried out to ascertain the degree of causality in the variables on one another. Causality test examines whether past changes in one variable $X$, help to explain current changes in another variable, over and above the ex- 
planation provided by the past changes in $Y$ if, otherwise, one concluded that $X$ does not granger cause $Y$.

\subsection{Identification of Variables and Data Source}

The variables used are as follows: inflation rate, money supply, interest rate, exchange rate, oil revenue, and government expenditure from 1970-2008.

The study used the time-series data generated from secondary data from the CBN Statistical Bulletin (2010) [17].

\section{Result}

In an attempt to examine the relationships between money supply and inflation in Nigeria, this section begins by examining the descriptive statistics of the data series employed in the study in Table 1.

Table 1 shows the value of standard deviation for each of the variables. The mean values are also presented in the Table. For instance, mean value for oil revenue is 865485.1, while that for money supply is 466657.7. The Jargue-Bera (JB) statistics indicates that most of the data series have normal distribution. This is indicated by the probability value of JB statistics which for most series are significantly different from zero at $1 \%$ levels of significance.

Table 2 shows the degrees of association between all the identified variables displayed. The first row of the matrix in the Table 2 above shows the relationships between money supply and other variables. It is observed that exchange rate has negative relationships with money supply. From the second row, it is also observed that, government expenditure and oil revenue are negatively related to inflation. The third row shows how exchange rate is related to other variables.

Figure 1 shows the scatter plot matrices between money supply, inflation rate, exchange rate, government expenditure oil revenue and interest rate. This is used to look at the relationships between all these variables. In each plot, the variable to the side of the graph is used as the $Y$ Variable, and the variable above or below the graph is used as the $X$ Variable (Ulrich et al., 2008) [18]. In the first line of Figure 1 are scatter plots of money supply against inflation rate, exchange rate, government expenditure, oil revenue and interest rate. In Figure 2, the first row has three panels. Panel 1 shows fluctuations in inflation rate for the periods covered in the study. It is indicated that inflation was low in 1970 while very high between 1990 and 2000. Panel 2 shows that while money supply was low between 1970 and 1990, it continued to rise and reached its peak in 2008. In the second row, Panels 1 and 2 show that both government expenditure and oil revenue vary between 2000 and 2008 .

Panel 3 demonstrates the oscillating nature of interest rate and that it was high in the early 1990s.

Figure 3 shows inflation for each level of money supply. For instance, when the level of money supply was 201414.5 the rate of inflation was $72.8 \%$ but when money supply was $4,857,545$ the level of inflation was $15.1 \%$.

In order to test for stationarity in this research, the Augmented Dickey Fuller (ADF) (1981) Unit Root Test is used and $5 \%$ critical value is selected.

The results in Table 3 show that all the variables are not

Table 1. Descriptive statistics.

\begin{tabular}{|c|c|c|c|c|c|c|}
\hline & Msply & Infr & Exhr & Gexp & Oilrev & Intr \\
\hline Mean & 466657.7 & 19.84359 & 2576.348 & 463733.3 & 865485.1 & 17.37103 \\
\hline Maximum & 4857544 & 72.80000 & 99095.00 & 3240820 & 6530630 & 36.09000 \\
\hline Minimum & 227.4640 & 3.200000 & 0.546400 & 903.9000 & 8.000000 & 6.000000 \\
\hline Std. Dev. & 981212.3 & 16.46757 & 15862.15 & 775924.3 & 1683153. & 7.343720 \\
\hline Skewness & 3.006919 & 1.561027 & 6.002095 & 1.979227 & 2.105636 & 0.502089 \\
\hline Kurtosis & 12.49888 & 4.780994 & 37.02556 & 6.375923 & 6.275795 & 2.526552 \\
\hline Jarque-Bera & 205.3917 & 20.99363 & 2115.489 & 43.98261 & 46.25666 & 2.002859 \\
\hline Sum & 18199650 & 773.9000 & 100477.6 & 18085597 & 33753919 & 677.4700 \\
\hline Sum Sq. Dev. & $3.66 \mathrm{E}+13$ & 10304.88 & $9.56 \mathrm{E}+09$ & $2.29 \mathrm{E}+13$ & $1.08 \mathrm{E}+14$ & 2049.349 \\
\hline Observations & 39 & 39 & 39 & 39 & 39 & 39 \\
\hline
\end{tabular}

Source: author's computations. 
Table 2. Correlation matrix.

\begin{tabular}{ccccccc}
\hline & Msply & Infr & Exhr & Gexp & Oilrev & Intr \\
\hline MSPLY & 1.000000 & 0.172021 & -0.068939 & 0.965209 & 0.934737 & 0.198168 \\
INFR & -0.172021 & 1.000000 & -0.068915 & -0.198050 & -0.191470 & 0.317687 \\
EXHR & -0.068939 & -0.068915 & 1.000000 & -0.081296 & -0.074526 & 0.078188 \\
GEXP & 0.965209 & -0.198050 & -0.081296 & 1.000000 & 0.969426 & 0.297278 \\
OILREV & 0.934737 & -0.191470 & -0.074526 & 0.969426 & 1.000000 & 0.208863 \\
INTR & 0.198168 & 0.317687 & 0.078188 & 0.297278 & 0.208863 & 1.000000 \\
\hline
\end{tabular}

Source: author's computations.

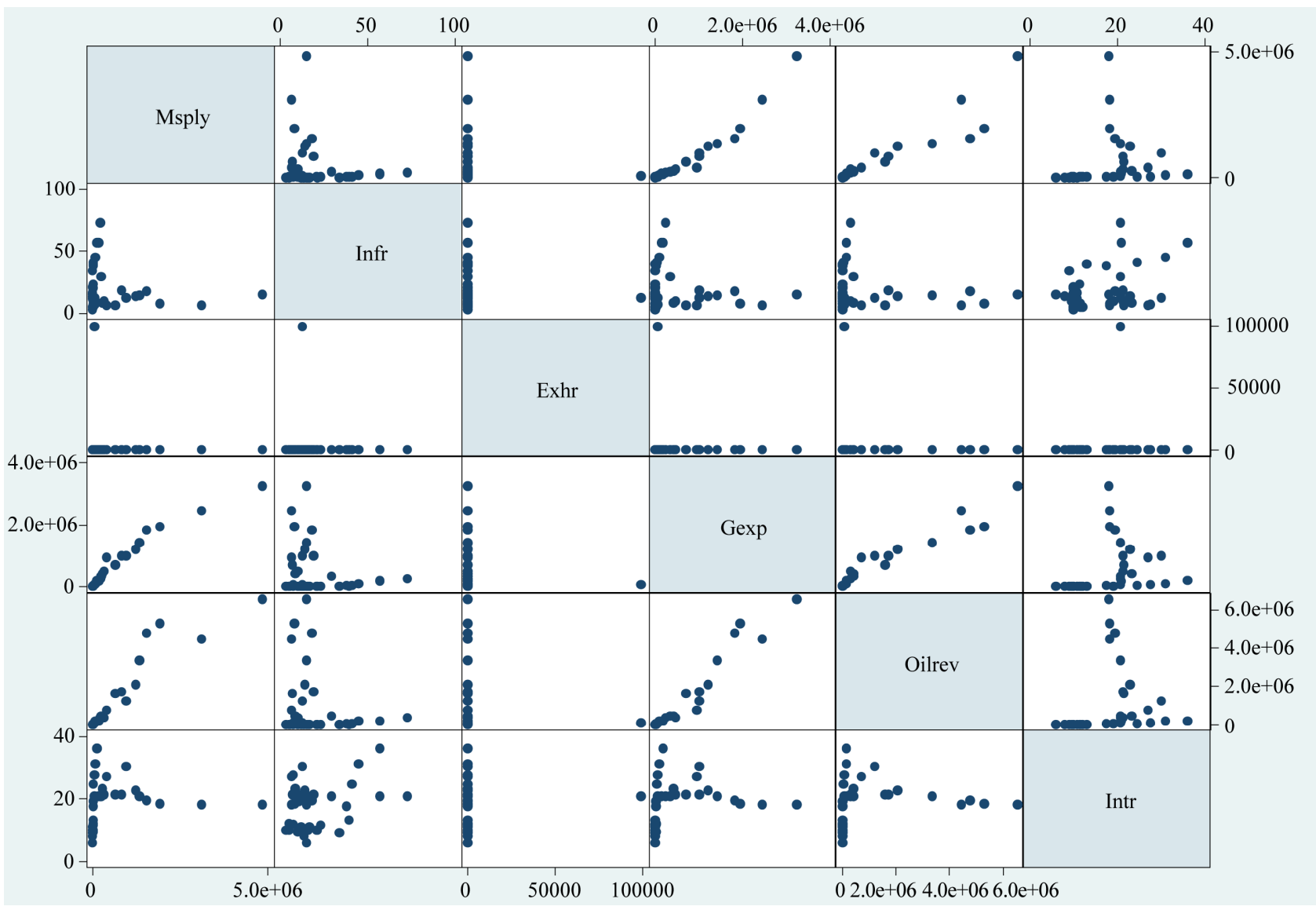

Figure 1. The scatterplot matrix showing the relationship among the macreconomic indicators in the study.

stationary at levels. This can be seen by comparing the test statistics with the critical values. The result shows that oil revenue and interest rate are not stationary at the level.

The Unit root test shows that both, oil revenue and interest rate are stationary at the first difference. As a result of the fact that all the variables are not stationary at the level, the long run relationship among the variables fitted in the model was tested while using the co integration test. The result shows that there is a long run relationship because there is one co-integrating vector.

The result in Table 5 shows that money supply is posi- tively related to inflation. This answers the question, and show that there is a relationship between money supply and inflation rate in Nigeria. And that money supply is a major determinant of inflation. Exchange rate, interest rate and government expenditure are inversely related to inflation. With 1 percent increase in money supply, inflation will increase by 152 percent. Also, with a 1 percent change in exchange rate and interest rate; inflation got reduced by 207 and 139 percents respectively. From this, it can be inferred that money supply, exchange rate and interest rate determine inflation in Nigeria. 

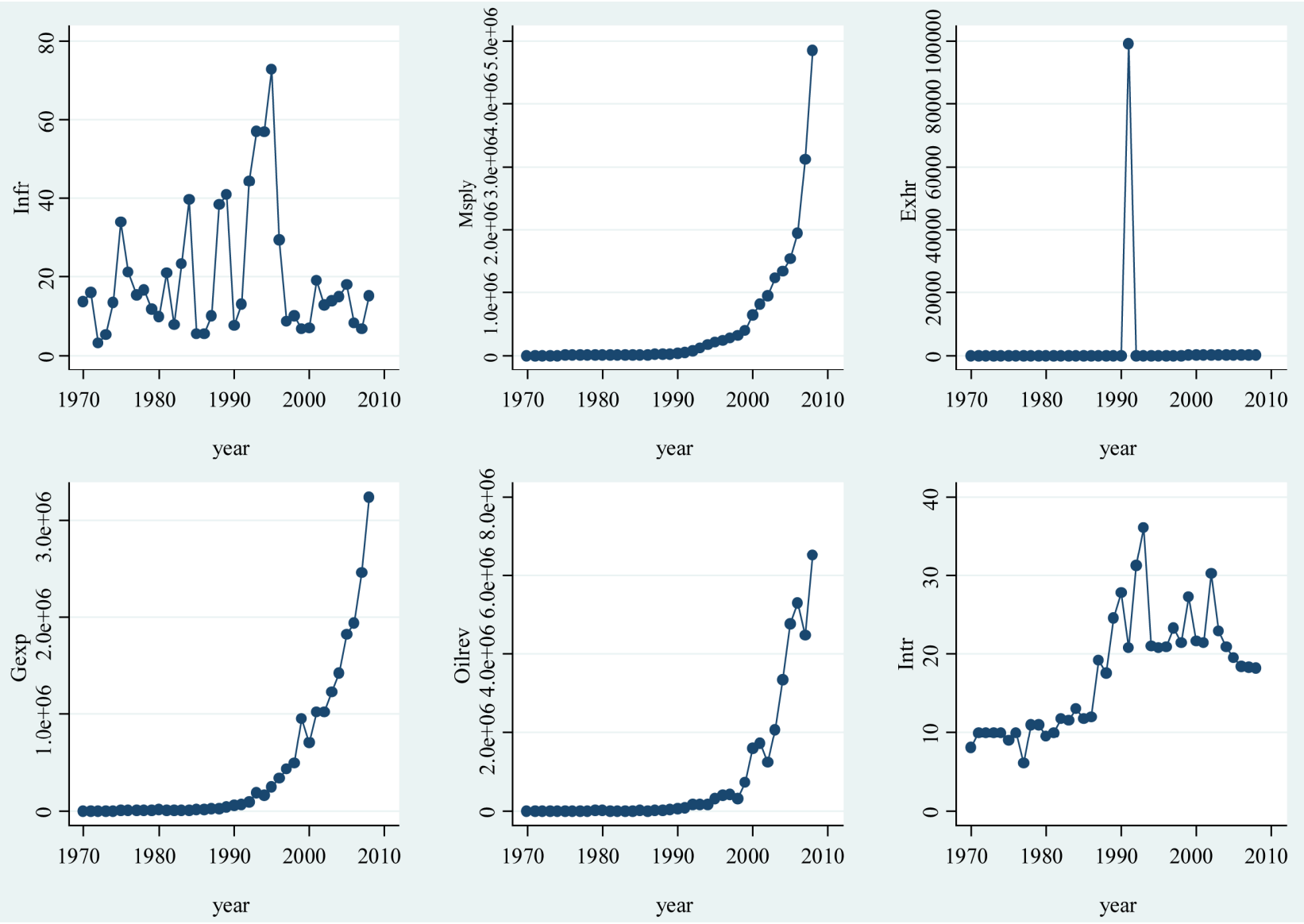

Figure 2. Monet supply, inflation rate, interest rate, exchange rate, government expenditure and oil revenue in Nigeria between 1970-2008.

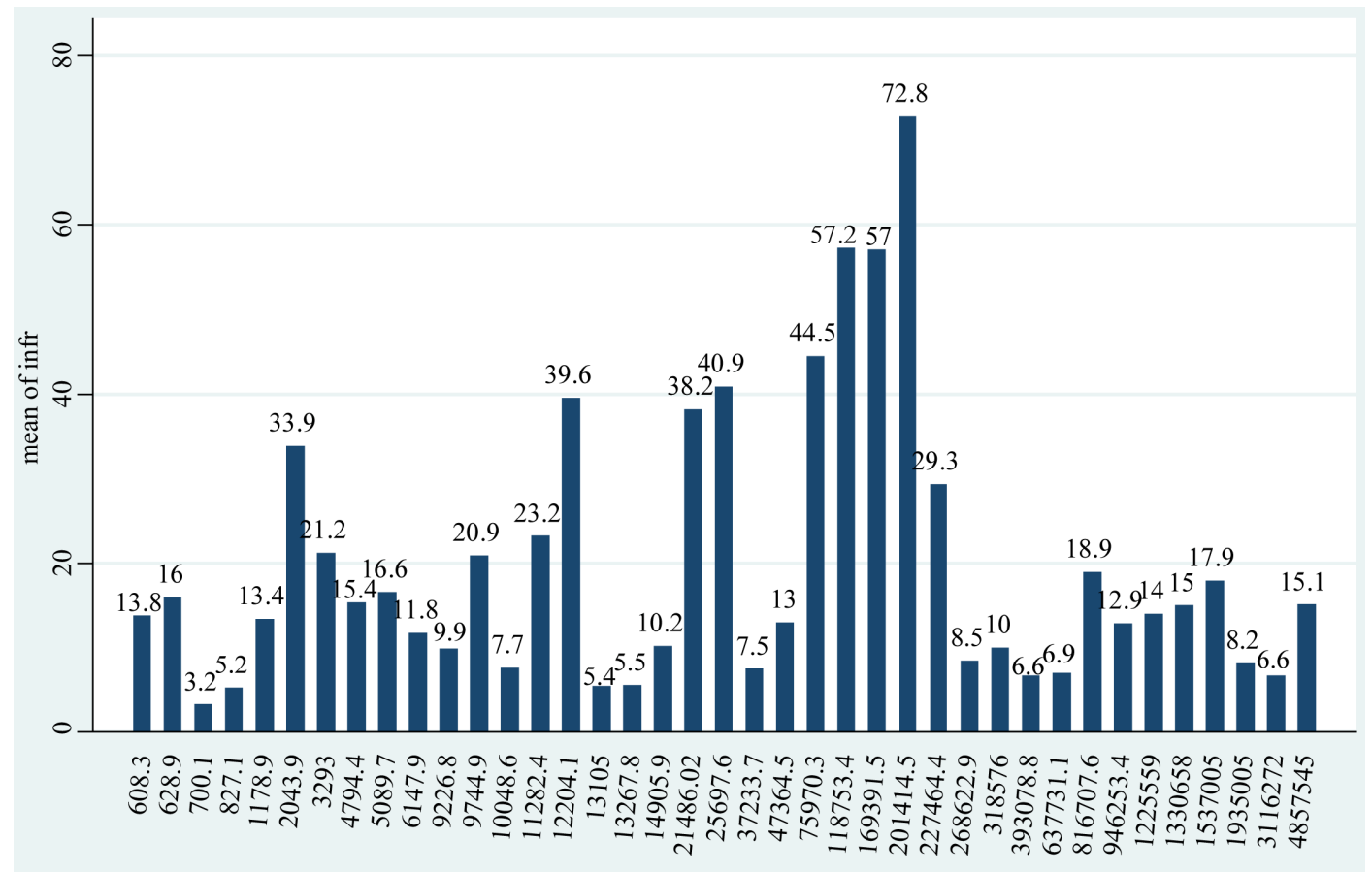

Figure 3. Monet supply and level of inflation. 
Table 3. Test for unit root.

\begin{tabular}{ccccc}
\hline Variables & Test Statistics & $\mathbf{5 \%}$ Critical Value & Level & S/NS \\
\hline Msply & 8.335324 & 2.967767 & $1(0)$ & $\mathrm{S}$ \\
Exhr & 6.167499 & 2.941145 & $1(0)$ & $\mathrm{S}$ \\
Gexp & 4.055704 & 2.963972 & $1(0)$ & $\mathrm{S}$ \\
Oilrev & 0.396410 & 2.957110 & $1(1)$ & $\mathrm{NS}$ \\
Intr & 2.208853 & 2.941145 & $1(1)$ & $\mathrm{NS}$ \\
\hline
\end{tabular}

Source: author's computations.

Table 4. Test for cointegration (long run relationship).

\begin{tabular}{ccccc}
\hline & Likelihood & 5 Percent & 1 Percent & Hypothesized \\
\hline Eigenvalue & Ratio & Critical Value & Critical Value & No. of CE (s) \\
0.900246 & 201.2321 & 94.15 & 103.18 & None \\
0.735159 & 115.9451 & 68.52 & 76.07 & At most 1 \\
0.630247 & 66.78591 & 47.21 & 54.46 & At most 2 \\
0.488458 & 29.97390 & 29.68 & 35.65 & At most 3 \\
0.129531 & 5.171855 & 15.41 & 20.04 & At most 4 \\
0.001056 & 0.039108 & 3.76 & 6.65 & At most 5 \\
\hline
\end{tabular}

Table 5. Relationship between macroeconomic variables.

\begin{tabular}{ccccc}
\hline Variable & Coefficient & Std. Error & t-Statistic & Prob. \\
\hline C & 2.832937 & 6.431873 & 0.440453 & 0.6625 \\
MSPLY & 1.523841 & 0.002153 & 1.841202 & 0.0173 \\
EXHR & -2.073514 & 0.000153 & -1.107445 & 0.0251 \\
GEXP & $-4.85 \mathrm{E}-05$ & $2.02 \mathrm{E}-05$ & -2.395698 & 0.0224 \\
OILREV & $8.29 \mathrm{E}-06$ & $6.25 \mathrm{E}-06$ & 1.326830 & 0.1937 \\
INTR & -1.387255 & 0.396239 & 3.469692 & 0.0015 \\
R-squared & 0.852831 & Mean dependent var & 19.84359 \\
Adjusted R-squared & 0.762152 & S.D. dependent var & 16.46757 \\
S.E. of regression & 14.72485 & Akaike info criterion & 8.357589 \\
Sum squared resid & 7155.104 & \multicolumn{2}{c}{ Schwarz criterion } & 8.613522 \\
Log likelihood & -156.9730 & \multicolumn{2}{c}{ F-statistic } & 2.905407 \\
Durbin-Watson stat & 1.483458 & \multicolumn{2}{c}{ Prob (F-statistic) } & 0.027876 \\
\hline
\end{tabular}

Granger causality tests are conducted to determine whether the current and lagged values of one variable affect another. The result of the pair wise granger causality test among money supply, inflation rate, exchange rate, government expenditure, oil revenue and interest rate are showed in the Table 6.

The results indicate that no causality exists between inflation and money supply, exchange rate and money supply, interest rate and money supply, government expenditure and inflation rate, oil revenue and inflation rate, government expenditure and exchange rate, oil revenue and exchange rate, interest rate and government expenditure as well as interest rate and oil revenue. This indicates that no causality runs between the variables.

The result from the causality test indicates that there exists a unidirectional causality between exchange rate and inflation rate, interest rate and inflation rate. The causality test runs from the exchange rate to inflation. Also, causality runs from interest rate to inflation rate. Unidirectional causality is also observed between money supply and government expenditure, exchange rate and interest rate. Also, causality runs from money supply to government expenditure and exchange rate to interest rate. There is bi-directional relationship between oil revenue and money supply, oil revenue and government expenditure. The implication of this is that increase in money supply leads to government expenditure which, in turn leads to change in household income. The Nigerian government is however, heavily dependent on oil revenue as its major source of income.

The Impulse Response Function was tested for in this study. According to Adebiyi (2006) [19] and Olorunfemi (2010) [20], impulse response analysis is used to uncover the dynamic relationships between macroeconomic variable within vector-autoregressive (VAR) models. It measures the time profile of the effect of a shock or impulse on the (expected) future values of a variable. Figure 4 shows the results of the IRF for the VAR model fitted in this study. The first row panel represents IRF of inflation rate due to itself and other variables. Own shock raised manufacture in the first two years that came down to negative and slightly rose to flatten out. The shock in money supply had no early effect on inflation rate but later had a slight positive effect on inflation rate. Exchange rate, interest rate and government expenditure had no impact on inflation rate.

Oil revenue had a long run impact on inflation rate. The second row of the panel represents IRF of money supply to itself and other variables in the VAR model. Money supply had a long run positive impact on inflation rate for the period. Own shocks had an immediate and sustaining positive impact on money supply. However money supply had no impact on interest rate. Money supply had later positive impact on both government expenditure and oil revenue. The third row panel represents IRF of exchange rate to other variables in the VAR model. It seems clear that inflation rate, government expenditure, interest rate and money supply seems to have permanent neutral or no impact on the exchange rate except a slight positive impact by money supply. The fourth row panel represents IRF of government expenditure to 
Table 6. Gwise granger causality tests.

\begin{tabular}{|c|c|c|c|}
\hline Null Hypothesis: & Obs & F-Statistic & Probability \\
\hline $\begin{array}{l}\text { INFR does not Granger Cause MSPLY } \\
\text { MSPLY does not Granger Cause INFR }\end{array}$ & 37 & $\begin{array}{l}1.68557 \\
0.60610\end{array}$ & $\begin{array}{l}0.20138 \\
0.55162\end{array}$ \\
\hline $\begin{array}{l}\text { EXHR does not Granger Cause MSPLY } \\
\text { MSPLY does not Granger Cause EXHR }\end{array}$ & 37 & $\begin{array}{l}0.03588 \\
0.12740\end{array}$ & $\begin{array}{l}0.96480 \\
0.88083\end{array}$ \\
\hline $\begin{array}{l}\text { GEXP does not Granger Cause MSPLY } \\
\text { MSPLY does not Granger Cause GEXP }\end{array}$ & 37 & $\begin{array}{l}0.13590 \\
9.55540\end{array}$ & $\begin{array}{l}0.87343 \\
\mathbf{0 . 0 0 0 5 6}\end{array}$ \\
\hline $\begin{array}{l}\text { OILREV does not Granger Cause MSPLY } \\
\text { MSPLY does not Granger Cause OILREV }\end{array}$ & 37 & $\begin{array}{l}18.2463 \\
61.1491\end{array}$ & $\begin{array}{l}5.2 \mathrm{E}-06 \\
1.2 \mathrm{E}-11\end{array}$ \\
\hline $\begin{array}{l}\text { INTR does not Granger Cause MSPLY } \\
\text { MSPLY does not Granger Cause INTR }\end{array}$ & 37 & $\begin{array}{l}1.48172 \\
0.05918\end{array}$ & $\begin{array}{l}0.04242 \\
0.94264\end{array}$ \\
\hline $\begin{array}{l}\text { EXHR does not Granger Cause INFR } \\
\text { INFR does not Granger Cause EXHR }\end{array}$ & 37 & $\begin{array}{l}3.35513 \\
2.56934\end{array}$ & $\begin{array}{l}\mathbf{0 . 0 4 7 5 5} \\
0.09229\end{array}$ \\
\hline $\begin{array}{l}\text { GEXP does not Granger Cause INFR } \\
\text { INFR does not Granger Cause GEXP }\end{array}$ & 37 & $\begin{array}{l}0.62464 \\
0.11204\end{array}$ & $\begin{array}{l}0.54186 \\
0.89436\end{array}$ \\
\hline $\begin{array}{l}\text { OILREV does not Granger Cause INFR } \\
\text { INFR does not Granger Cause OILREV }\end{array}$ & 37 & $\begin{array}{l}0.40579 \\
0.10690\end{array}$ & $\begin{array}{l}0.66983 \\
0.89889\end{array}$ \\
\hline $\begin{array}{l}\text { INTR does not Granger Cause INFR } \\
\text { INFR does not Granger Cause INTR }\end{array}$ & 37 & $\begin{array}{l}3.11337 \\
1.83947\end{array}$ & $\begin{array}{l}\mathbf{0 . 0 5 8 1 5} \\
0.17531\end{array}$ \\
\hline $\begin{array}{l}\text { GEXP does not Granger Cause EXHR } \\
\text { EXHR does not Granger Cause GEXP }\end{array}$ & 37 & $\begin{array}{l}0.14306 \\
0.31922\end{array}$ & $\begin{array}{l}0.86725 \\
0.72900\end{array}$ \\
\hline $\begin{array}{l}\text { OILREV does not Granger Cause EXHR } \\
\text { EXHR does not Granger Cause OILREV }\end{array}$ & 37 & $\begin{array}{l}0.10971 \\
0.06776\end{array}$ & $\begin{array}{l}0.89643 \\
0.93462\end{array}$ \\
\hline $\begin{array}{l}\text { INTR does not Granger Cause EXHR } \\
\text { EXHR does not Granger Cause INTR }\end{array}$ & 37 & $\begin{array}{l}1.21152 \\
6.76942\end{array}$ & $\begin{array}{l}0.31104 \\
\mathbf{0 . 0 0 3 5 3}\end{array}$ \\
\hline $\begin{array}{l}\text { OILREV does not Granger Cause GEXP } \\
\text { GEXP does not Granger Cause OILREV }\end{array}$ & 37 & $\begin{array}{l}6.01106 \\
13.1993\end{array}$ & $\begin{array}{l}0.00608 \\
6.6 E-05\end{array}$ \\
\hline $\begin{array}{l}\text { INTR does not Granger Cause GEXP } \\
\text { GEXP does not Granger Cause INTR }\end{array}$ & 37 & $\begin{array}{l}0.18426 \\
0.11096\end{array}$ & $\begin{array}{l}0.83260 \\
0.89532\end{array}$ \\
\hline $\begin{array}{l}\text { INTR does not Granger Cause OILREV } \\
\text { OILREV does not Granger Cause INTR }\end{array}$ & 37 & $\begin{array}{l}0.70459 \\
0.37447\end{array}$ & $\begin{array}{l}0.50182 \\
0.69063\end{array}$ \\
\hline
\end{tabular}

Source: author's computations.

other variables in the VAR model. The shocks in inflation rate, exchange rate and interest rate have no impact on government expenditure while money supply had an immediate and a sustaining positive impact on government expenditure. The fifth row panel represents IRF of oil revenue to itself and other variables. Only money supply had early and prolonged positive impact on oil revenue, while the impact of inflation rate, exchange rate, government expenditure and interest rate are not noticeable. However, the impact of oil revenue to itself was negative from the eighth year to the end of the tenth year before getting back to neutrality. The last row panel represents IRF of interest rate to other variables in the VAR model. The shocks in interest rate had no impact on inflation rate in all the periods. Also exchange rate, government expenditure and interest rate had neutral impact all through. Money supply had an early neutral impact up to the seventh year and thereafter turned negative till the end of the period. The impulse response function for all the variables fitted in the VAR model in the study sug- gests that there is both short-run and long-run impact of money supply, exchange rate, government expenditure, oil revenue and interest rate on inflation rate in Nigeria.

\section{Policy Implication and Conclusions}

This study examined money supply and inflation in Nigeria. For this, the study looked at the key determinants of inflation in Nigeria to determine the relationship(s) between inflation and money supply. It also examined the trends and magnitudes of inflation in Nigeria.

The following are the findings and possible areas of intervention:

The study reveals that the result from the causality test indicates that there exists a unidirectional causality between exchange rate and inflation rate, interest rate and inflation rate. The causality test runs from money supply to inflation, from exchange rate to inflation, and from interest rate to inflation rate. Unidirectional causality is also noticed between money supply and government expenditure, exchange rate and interest rate. Also, causality 


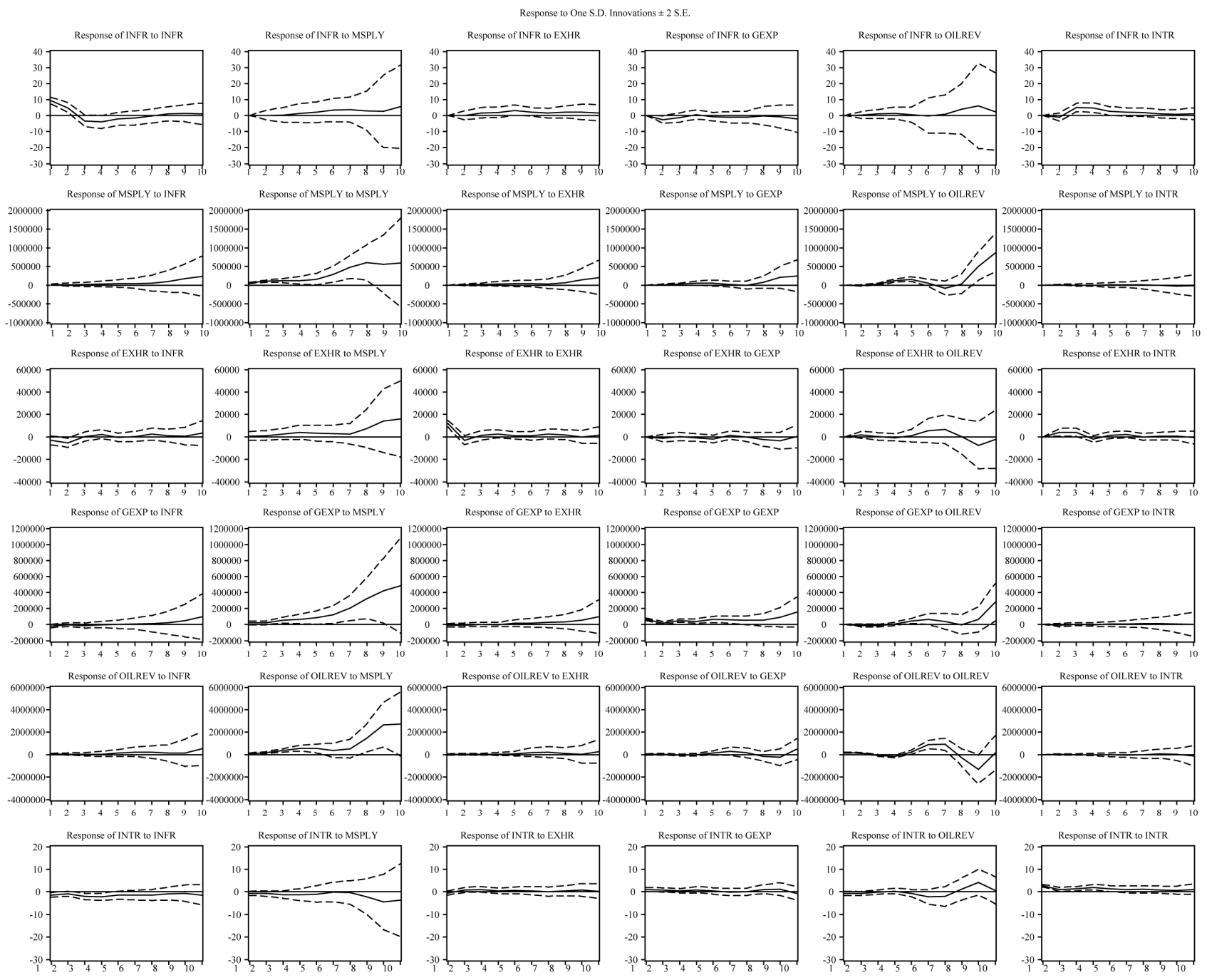

Figure 4. Impulse response function.

runs from money supply to government expenditure and also exchange rate to interest rate. There is a bi-directional relationship between oil revenue and money supply, and oil revenue and government expenditure. The implication of this is that increase in money supply leads to government expenditure and which, in turn, leads to change in household income.

The study also shows that there is a positive relationship between money supply and inflation rate. This supports the study of Egwaikhide et al. (1994) [15] that inflation in Nigeria seems to find explanation in money supply. As a result, the government of Nigeria should put in place serious reforms that will ensure that more of the money in the circulation is in the productive sector.

From the study too, interest rates have an important impact on monetary expansion in the economy. It is therefore rational to confirm the market forces of demand and supply. For example, relatively easy monetary policy for the expansion of money supply aims at inducing banks to reduce their lending rates in order to provide low cost credit to the private sector and thus giving a real boost to the economy and vice versa. Government should use the level of inflation as an operational guide in measuring the effectiveness of its monetary policy. Hence, if these policy measures, for the control of money supply in the economy, were to be applied, they may be helpful in the control of monetary expansion.

\section{REFERENCES}

[1] J. K Onoh, "The State of the Nigeria Economy: An Overview of Structural Adjustment Programme in Nigeria: Impact of SFEM on the Nigeria Economy," Nigerian Institute of International Affairs, Lagos. 1990.

[2] E. J. Hamilton, "The Role of War in Modern Inflation," Journal of Economic History, Vol. 37, No. 1, 1977, pp. 13-19. doi: $10.1017 / \mathrm{S} 0022050700096686$

[3] M. C. Vaish, "Macroeconomics Theory," 11th Edition, UBS Publishers' PVT Ltd., New Delhi, 2002. 
[4] A. J. Chhibber, et. al., "Inflation Price Controls and Fiscal Adjustment in Zimbabwe," Working Paper No. WPS192, The World Bank, Washington DC, 1989, pp. 21-37.

[5] A. L. Kilindo, "Fiscal Operations, Money Supply and Inflation in Tanzania," African Economic Research Consortium, AERC Research Paper No. 65, Nairobi, 1997.

[6] B. M. Barungi, "Exchange Rate Policy and Inflation: The Case of Uganda," African Economic Research Consortium, AERC Research Paper No. 59, Nairobi, 1997.

[7] S. A Laryea and U. R. Sumaila, "Determinants of Inflation in Tanzania," Chr. Michelson Institute, CMI WorkingPapers WP/2001/12 Bergen, Norway, 2001.

[8] T. A. Oyejide, "Deficit Financing, Inflation and Capital Formation. The Analysis of the Nigerian Economy, 19571970," Nigerian Journal of Economics and Social Studies, Vol. 14, No. 1, 1972, pp. 22-43.

[9] G. Itua, "Structural Determinants of Inflation in Nigeria (1981-1990)," An Unpublished M.Sc. Thesis, Department of Economics, Ahmadu Bello University, Zaria, 2000.

[10] M. Iyoha, "Budget of Economic Growth and Development," Bullion Publication of CBN, Vol. 26, No. 2, 2002, pp. 12-27.

[11] R. A. Ajisafe, "An Empirical Investigation of the Determinants of Inflation in Nigeria," Ife Journal of Economics and Finance, Vol. 3, No. 1-2, 1996, pp. 65-94.

[12] B. A. Folorunso and A. G. Abiola, "Long-Run Determinants of Inflation in Nigeria (1970-1998)," Nigeria Jour- nal Economics and Social Studies, Vol. 42, No. 1, 2000, pp. 10-26.

[13] J. O. Osakwe, "Government Expenditure, Money Supply and Prices: 1970-1980," CBN Economic and Financial Review, Vol. 21, No. 2, 1983, pp. 23-42.

[14] M. A. Onitiri and K. Awosika, "Inflation in Nigeria," Proceedings of a National Conference convened by the Nigerian Institute of Social and Economic Research, Ibadan, 1982.

[15] F. O. Egwaikhide, "Patterns of Government Revenue and Expenditure in Nigeria: A Historical Survey," An Unpublished M.Sc. Thesis, University of Ibadan, Nigeria, 1994.

[16] M. Z. Abdul Majid, "Causality Link between Money, Output and Prices in Malaysia: An Empirical Re-Examination," Applied Econometrics and International Development, Vol. 7, No. 1, 2007, pp. 81-93.

[17] CBN, "CBN Statistical Bulletin," 50th Anniversary Edition, Lagos, 2010.

[18] K. Ulrich and K. Frauke, "Data Analysis Using Stata," 2nd Edition, Stata Press, Texas, 2008.

[19] M. A. Adebiyi, "Public Expenditure and Human Capital in Nigeria: An Autoregressive Model," 2006. www.isser.org/43\%20Adebayo.Pdf

[20] S. Olorunfemi, "Infrastructural Services and Manufacturing Growth in Nigeria: A Dynamic Analysis," The Indian Journal of Economics, Vol. 6, No. 2, 2008. 